\title{
PERANCANGAN E-GOVERNMENT PADA KECAMATAN DAN KELURAHAN KOTA SAMARINDA
}

\author{
Faza Alameka *,1, Aulia Rahman ${ }^{2}$, Reza Nur Muhammad ${ }^{3}$ \\ ${ }^{1}$ Magister Teknologi Informasi. Universitas Ahmad Dahlan \\ ${ }^{2,3}$ Teknik Informatika Fakultas Ilmu Komputer dan Teknologi Informasi Universitas Mulawarman \\ Jalan Prof. Dr. Soepomo, S.H., Umbulharjo, Daerah Istimewa Yogyakarta \\ Kampus Gunung Kelua Barong Tongkok Samarinda, Kalimantan Timur \\ E-Mail : faza.alameka@gmail.com ${ }^{1}$, zero123@gmail.com² ${ }^{2}$ ezanurm@gmail.com ${ }^{3}$
}

\begin{abstract}
ABSTRAK
Kecamatan dan Kelurahan merupakan salah satu lembaga yang mempunyai peranan penting dalam pemerintahan dan penyelenggaraan administrasi kemasyarakatan. Salah satu instansi pemerintahan yang dituntut terus memperbaharui data-data yang ada di kecamatan dan kelurahan di Kota Samarinda. Manfaat data-data yang ada di kecamatan dan kelurahan adalah untuk mempermudah berbagai pihak yang memerlukan informasi dan data dari suatu wilayah khususnya masyarakat yang tinggal di kecamatan dan kelurahan tersebut. Dalam penulisan ini, penulis menjelaskan tentang perancangan M-government kecamatan dan kelurahan menjadikan masyarakat informasi. Dalam perancangan sistem ini penulis menggunakan pendekatan Model Protype yang setiap tahapantahapan tersebut dilakukan secara berurutan. Setiap bagian yang sudah selesai dilakukan testing kemudian dikirim kepada pemakai untuk langsung dapat dipresentasikan sebagai bahan acuan sistem yang baru. Pembuatan perancangan sistem ini menggunakan sistem informasi terintegrasi server-side berbasis mobile yang memungkinkan masyarakat umum mendapatkan informasi Kecamatan dan Kelurahan Kota Samarinda.
\end{abstract}

Kata Kunci : Kelurahan dan Kecamatan, Data, Model Protype, Mobile.

\section{PENDAHULUAN}

Kota Samarinda yang dikenal sebagai Kota Tepian, dulunya salah satu wilayah Kesultanan Kutai Kartanegara di Martadipura. Sampai pertengahan abad ke-17, Wilayah Kota Samarinda merupakan lahan persawahan dan perladangan itu umumnya dipusatkan disepanjang tepi Sungai Karang Humus dan Sungai karang Asam.dalam berapa decade, kota samarinda mengalami pertumbuhan pada berapa bidang dan sektor namun ada juga yang mengalami penurunan. Dengan hal ini, Pemerintah Kota Samarinda tidak boleh lengah untuk terus meningkatkan pelayanan daerah sehingga pelayanan kepada masyarakat Kota Samarinda dapat di tingkatkan [1] Secara yuridis Kota Samarinda terbentuk berdasarkan UndangUndang Republik Indonesia Nomor 27 Tahun 1959. Kecamatan dan Kelurahan merupakan suatu lembaga kepemerintahan yang sangat mempunyai peranan peting dalam pemerintahan dan penyelenggaraan administrasi kemasyarakatan Kota Samarinda memiliki 10 Kecamatan dan 53 Kelurahan yang terbentuk dalam Peraturan Daerah Kota Samarinda Nomer 2 Tahun 2014 tentang Rencana Tentang Tata Ruang Kota Samarinda Tahun 2014-2034. Yang menjelaskan tentang terbentuknya 53 Kelurahan dan batas-batas Kelurahan yang ada di Kota Samarinda [2] Dari hasil penelilitian yang telah dilakukan dengan terkait dengan data-data yang ada di Kecamatan dan

*Corresponding Authors

Email : faza.alameka@gmail.com
Kelurahan yang ada di Kota Samarinda belum terkelola dengan baik dan belum banyak masyarakat sekitar Kecamatan dan Kelurahan yang mengetahui tentang data apasaja yang ada di Kecamatan dan Kelurahan yang masyarakat tinggal, data yang ada dalam rangkaian sistem manajemen data sekarang digunakan oleh pihak Kecamatan dan Kelurahan yang ada di Kota Samarinda sangat kurang efektif [3]. Data Umum dan Data Monografi Kecamatan dan Kelurahan di Kota Samarinda yang sekarang ada dalam instansi yang terkait dan masih bersifat lembaran kertas dari setiap laporan Kecamatan dan Kelurahan dan kemudian akan di laporkan dan di publikasi kepada masyarakat namunpun itu masih berbentuk kertas [3]. Dalam perancangan Mobile Government (studi kasus Kecamatan dan Kelurahan di Kota Samarinda) akan di rancang dengan menggunakan server-side berbasis web dan mobile yang memungkinkan pengembangan sistem yang dinamis dan dapat di gunakan oleh semua kalangan masyarakat (user friendly). Daya yang disimpan dalam bentuk database (Bank Data) sehingga mempuyai efesiensi dan user friendly. Pengembangan dan perubahan sistem dapat dilakukan dengan mudah dan terpusat oleh server, sedangkan aplikasi yang digunakan dalam bentuk web dan mobile yang user friendly. Kecamatan dan Kelurahan yang di Kota Samarinda saatnya memanfaatkan Teknologi Informasi dan Komunikasi yang dapat memudahkan bagi semua pihak yang berkepentingan yang memerlukan daya 
di dalam mencapai suatu tujuan yang telah direncanakan Walikota Kota Samarinda yang mempunyai Program SMART CITY dan pengembangan kualitas Kota Samarinda. [4]

\section{TINJAUAN PUSTAKA}

\subsection{Landasan Teori}

\section{Kota Samarinda}

Kota Samarinda merupakan Ibu Kota Provinsi Kalimantan Timur, serta kota terbesar di Kalimantan. Seluruh wilayah kota ini berbatasan langsung dengan Kabupaten Kutai Kartanegara, Kota Samarinda dapat dicapai dengan perjalanan darat, laut ataupun udara. Dengan sungai Mahakam membelah di tengah Kota Samarinda, [1] yang menjadi "Gerbang" menuju pedalaman Kalimantan Timur. Kota ini memiliki luas wilayah 718 kilometer persegi dan berpenduduk 805.688 jiwa pada tahun 2013 (Badan Pusat Statistik Kota Samarinda), menjadikan Kota ini berpenduduk terbesar di seluruh Kalimantan. [5]

\section{Kecamatan}

Kecamatan adalah pembagian wilayah administratif di Indonesia dibawah Kabupaten atau kota [6]. Kota Samarinda memiliki 10 kecamatan yang terdiri dari Kecamatan palaran, Kecamatan Samarinda Seberang, Kecamatan Samarinda ULU, Kecamatan Samarinda ILIR, Kecamatan Samarinda Utara, Kecamatan Sungai Kunjang, Kecamatan Sambutan, Kecamatan Sungai Pinang, Kecamatan Samarinda Kota dan Kecamatan Loajanan ILIR. [7]

\section{Kelurahan}

Kelurahan adalah wilayah kerja lurah sebagai perangkat daerah Kota Samarinda dibawah Kecamatan. [8]

\section{4. e-Government}

E-Goventment adalah sebuah aplikasi elektronik baik itu menggunakan media internet maupun media perangkat digital lainnya, [9] yang digunakan oleh intitusi pemerintah dalam mencapaikan informasi dan pelayanan publik lainnya. [10] pada era serba teknologi informasi dan komunikasi ini, begitu banyak intitusi pemerintah yang gencar mempromosikan dan memperkenalkan informasi dan layanan yang dimilikinya melalui media internet/website. Mulai dari informasi dan layanan yang disediakan oleh pemerinta daerah hingga pusat, sampai pada informasi mengenai parawisata, peluang bisnis, hingga keluhan masyarakat. [11]

\section{5. m-Government}

M-Governmet adalah sebuah hasil dari eGovernment yang di kombinasikan dengan sebuah perangkat yang di sebut ponsel/handphone. $M$ government mengacu pada aplikasi dari komunikasi mobile komputasi dalam pekerjaan pemerintah. Yang menyediakan layanan masyarakat melalu ponsel, PDA, WI-FI dan lainnya. [12]

\subsection{Tujuan Penelitian}

Penelitian ini memiliki tujuan untuk membuat sebuah acuan atau perancangan sebuah sistem eGovernment yang akan di aplikasi dalam mobile technology yang akan di terapkan pada kecamatan dan kelurahan pada Kota Samarinda dan akan menjadi acuan bagi Kecamatan dan Kelurahan di Indonesia yang akan menerapkan e-Government yang di aplikasikan menggunakan Mobile Technologi dan untuk membantu Pemerintahan Kota Samarinda dalam menerapkan SMART CITY Pada Kota Samarinda. [4]

\subsection{Prosuder Penelitian}

Prosuder Penelitian yang akan dilakukan akan bermetodekan Metode Protype [13] yang di dalamnya terdiri sebagai berikut:

1. Pengumpulan data kebutuhan yaitu bertemu langsung dengan Camat dan Lurah yang ada di Kota Samarinda dan menentukan apa saja yang mereka butuhkan dalam memperbaharui sistem yang telah ada di Kecamatan dan Kelurahan , dan bertemu langsung dengan masyaakat yang tinggal di daerah Kecamatan dan Kelurahan Kota Samarinda untuk mendengar apa saja yang perlu dilakukan dan ditambahkan Kecamatan dan Kelurahan untuk meningkatkan kinerja dan transparansi data yang ada di Kecamatan dan Kelurahan Kota Samarinda kepada masyarakat sekitar.

2. Melakukan perancangan yang akan di terapkan pada Kecamatan dan Kelurahan Kota Samarinda dengan tidak melupakan konsep eGovernment yang bersifat USER FRIENDLY.

Melakukan evaluasi protype yang dilakukan bersama pihak-pihak Kecamatan, Kelurahan Pemerintah Kota Samarinda dan Walikota Kota Samarinda sampai menemukan rancangan sistem yang tepat untuk diterapkan di Kecamatan dan Kelurahan Kota Samarinda dan akan menjadi acuan SMART CITY[4] di Kota Samarinda pada bidang pemerintahan Kecamatan dan Kelurahan

\section{HASIL DAN PEMBAHASAN}

Hasil yang diharapkan dapat menjadikan rancangan sistem M-government dapat menjadi acuan pembentukan M-government pada Kecamatan dan Kelurahan yang ada di Indonesia dan dapat menjadikan sebuah alternatif kepada masyarakat yang tinggal pada Kecamatan dan Kelurahan yang tinggal pada daerah yang telah menggunakan sistem M-government Kecamatan dan Kelurahan yang ada di Kota Samarinda dan membantu program Walikota Kota Samarinda dalam menerapkan SMART CITY pada Kota Samarinda [4]

\section{KESIMPULAN DAN SARAN \\ 4.1 Kesimpulan}

Kecamatan dan Kelurahan merupakan salah satu lembaga yang mempunyai peranan penting dalam pemerintahan dan penyelenggaraan administrasi kemasyarakatan.[6] [8] Salah satu 
instansi pemerintahan yang dituntut terus memperperbaharui data-data dan penginformasian data-data dan Kegiatan yang ada di Kecamatan dan Kelurahan. Perancangan sistem M-government dapat memberikan kemudahan kepada masyarakat sekitar dengan adanya sistem yang terbaharui di Kecamatan dan Kelurahan dapat membantu program kerja Walikota Samarinda yang akan mengeinplementasikan SMART CITY pada Kota Samarinda.[4]

\subsection{Saran}

Penulis berharap perancangan ini dapat dikembangkan lebih kompleks/detail untuk mencapai sebuah konsep SMART CITY di Kota Samarinda. [4]

\section{DAFTAR PUSTAKA}

[1] Bappeda Kota Samarinda, (2015). Rencana Pembangunan Jangka Panjang Daerah Kota Samarinda tahun 2005-2025. Samarinda. Bappeda Kota Samarinda.

[2] PERDA Kota Samarinda No.2 Tahun 2014, (2014). Rencana Tata Ruang Wilayah Kota Samarinda Tahun 2014-2034. Samarinda. Pemerintah Kota Samarinda

[3] William Bongga. (2014). Pengembangan sistem manajemen data monografi dan statistik bidang pembangunan (studi kasus data monografi kelurahan Dadi Mulya). Samarinda. Skripsi di publikasi.
[4] Bappeda Kota Samarinda. (2015). Rancangan akhir RPJPD Kota Samarinda tahun 20052015. Samarinda. Bappeda Kota Samarinda.

[5] BPS Kota Samarinda. (2013). Samarinda Dalam angka Tahun 2013. Samarinda. Badan Pusat Statistik 2013.

[6] PERDA Kota Samarinda No.2 Tahun 2010. (2010) Pembentukan Kecamatan Sambutan, Kecamatan Samarinda Kota Kecamatan Sungai Pinang, dan Kecamatan Loa Janan Ilir dalam wilayah Kota Samarinda. Samarinda. Pemerintah Kota Samarinda

[7] https://id.wikipedia.org/wiki/Daftar_kecamata n_dan_kelurahan_di_Kota_Samarinda

[8] PERDA No1 Tahun 2006, (2006). Pembentukan Kelurahan dalam wilayah Kota Samarinda. Samarinda. Pemerintah Kota Samarinda.

[9] Gonang May Perdananugraha, (2010). Rancang bangun dan implementasi sistem informasi terintegrasi (INTEGRATED INFORMATION SYSTEM) E-GOVERNMENT Berbasis OPEN SOURCE. LIPI Press 2010, No.33, 45-59

[10] West, Darrel M., (2004), Global EGovernment, Center for Public Policy Brown University, Rhode Island, United States.

[11] The Working Group on E-Government in the Developing World. 2002. Roadmap for EGovernment in the Developing world. Pacific Council on International Policy, Los Angeles, CA United States

[12] Zhiqiang Wei, Xueyu Gao, Dongning Jia, Yongquan Yang. (2010). Research of Mobile Government Based on Multi-modal Platform with Unified Engine. IEEE, 978-1-4244-68379/10/\$26.00, 786-789 